\title{
Clinical and Epidemiologic Study of Hepatitis C Virus Genotype 4 Infection among Patients with B cell non Hodgkin's Lymphoma
}

\author{
Mohammad Al-Khashab ${ }^{1}$, Mohammad Emam ${ }^{1}$, Walid A. Abd El \\ Dayem $^{1}$, Ahmad S. Sherbini ${ }^{1}$, Nagla A. Abd El Wahab ${ }^{1}$, Noha E. \\ Shaheen $^{1}$, Ibrahim M Ibrahim ${ }^{1}$, Samar M. Abd-AlRaouf ${ }^{2}$ \\ ${ }^{1}$ Tropical Medicine Department, Faculty of Medicine, Zagazig University, Egypt \\ ${ }^{2}$ Pathology Departments, Faculty of Medicine, Zagazig University, Egypt
}

Corresponding Author Noha Shaheen

Mobile: +20100848587

9

E mail:

n.n1438@yahoo.com

Received $: 15 / 12$

12012

Accepted after

revision: $25 / 2 / 2012$

Key words: Hepatitis C, lymphoma, nonHodgkin, case-control study
Background and study aim: Many recent studies showed that chronic infection with hepatitis $\mathrm{C}$ virus (HCV) is associated with increased risk for B-cell non-Hodgkin's lymphoma (NHL). The aim of this study is to evaluate the frequency of $\mathrm{HCV}$ infection in a series of de novo B cell non Hodgkin's lymphoma (NHL) patients and to correlate virological findings with clinicohistological features.

Patients and methods: 50 patients with B cell NHL diagnosed by histopathology and immunophenotyping were recruited from Tropical medicine department and Oncology unit affiliated to Internal medicine department, Zagazig University hospitals. Gender and age matched controls $(\mathrm{N}=50)$ were volunteers selected from relatives of patients. Study participants were subjected to history taking, clinical examination, routine and specific laboratory tests. Anti-HCV antibody was determined by ELISA for

\section{INTRODUCTION}

The World Health Organization (WHO) estimates that 170 million people are infected with hepatitis $\mathrm{C}$ virus (HCV) [1]. An estimated 12$15 \%$ of Egyptians, have serological evidence of $\mathrm{HCV}$ infection (up to 99 $\%$ genotype 4 ), with higher rates in older age groups and residents of rural areas in lower and middle Egypt. There is evidence for a large-scale iatrogenic transmission of $\mathrm{HCV}$ during the parenteral antischistosomal treatment campaign carried out from the 1920s through the 1980s [2]. Continued transmission in Egypt has been associated with transfusion of unscreened blood, invasive surgical procedures, all study participants. HCV RNA PCR was done for all cases and HCV antibody positive controls. Appropriate radiologic examinations were performed.

Results: Frequency of HCV infections were statistically significantly higher in B cell NHL patients than in controls $(\mathrm{p}=$ 0.004). ALT levels were statistically significantly higher in $\mathrm{HCV}$ positive patients than in HCV positive controls (p $<0.001$ ) and HCV negative patients but without statistically significant difference $(p=0.067)$. There was no statistically significant difference in histologic types, grades and stages of NHL between HCV positive patients and $\mathrm{HCV}$ negative patients. Cryoglobulinemia showed no significant difference between studied groups.

Conclusion: $\mathrm{HCV}$ has a strong association with de novo B cell NHL, not complicating essential mixed cryoglobulinemia (EMC).

including Caesarean section and abortion; injections by informal health care providers and haemodialysis $[3$, 4].

Since its identification, HCV has been added to the roster of tumourassociated viruses because of its role in hepatocarcinogenesis. It has also been linked to extrahepatic disease manifestations [5]. One of the extrahepatic diseases in which $\mathrm{HCV}$ has been implicated is $\mathrm{B}$ cell non Hodgkin's lymphoma (NHL). HCV associated lymphomas have been observed, but whether they are caused by $\mathrm{HCV}$ remains to be shown definitively. 
There is a suggestion that some B-cell NHL associated with $\mathrm{HCV}$ arise from clonal expansion of B-cells with particular immunoglobulin gene rearrangements specific for the E2 protein of the $\mathrm{HCV}$ envelope [6]; which is consistent with the hypothesis that lymphomas develop when B cells proliferate in response to antigen. However, no biological mechanism of $\mathrm{HCV}$-associated lymphoma genesis has been definitively elucidated [7].

Most of the studies reported to date failed to find an association of $\mathrm{HCV}$ with NHL were conducted in areas where the prevalence of $\mathrm{HCV}$ was extremely low, leaving open the possibility that such an association actually exists but could not be detected because neither cases nor controls had adequate opportunity for exposure $[8,9,10]$. Working in a population with high prevalence of HCV allowed us to conduct a casecontrol study with adequate statistical power to assess the question of whether there is an association of chronic HCV infection with NHL [11].

Some studies investigated the sequel of $\mathrm{HCV}$ infection on the liver of patients with B cell NHL $[12,13]$. In the present study, we try to evaluate the frequency of $\mathrm{HCV}$ infection in a series of de novo B-cell non-Hodgkin's lymphoma (B NHL) patients and to correlate virological findings with clinico-histological features.

\section{PATIENTS AND METHODS}

50 patients with B cell NHL were collected from Tropical medicine department and Oncology unit affiliated to Internal medicine department. The diagnosis of B cell NHL was based on histopathology and confirmed by immunophenotyping. Of these cases, 25 were admitted at Tropical medicine department, because of generalized lymphadenopathy (7 patients), FUO (5 patients), anaemia (5 patients), persistent vomiting (3 patients), ascites (2 patients), anorexia and weight loss (2 patients) and bleeding tendency (1 patient). The other 25 cases were patients already diagnosed as B cell NHL and coming to receive chemotherapy in the Oncology unit.

The control group included 50 volunteers selected from relatives of patients admitted at Tropical medicine department and the Oncology unit. Controls were frequency-matched to cases by the 5-year age category and gender. Control subjects were representative of the source population of cases by region; since all cases and controls were from the region of Sharkia governorate. Controls were matched to cases as regard other risk factors of NHL; namely smoking and occupational exposure to industrial or agricultural pesticides. That is to have a more accurate assessment of $\mathrm{HCV}$ infection as a risk factor for NHL.

$\mathrm{HCV}$ infection among cases and control was defined as: positive HCV RNA PCR test with or without positive HCV antibody test. Positive HCV antibody test alone was not adopted to, minimize the false positive results of $\mathrm{HCV}$ infection among cases and controls in patients who catched the virus and cleared it, and minimize the false negative results of $\mathrm{HCV}$ infection among cases in patients who are immunocompromised and can not sustain antibody response to $\mathrm{HCV}$ infection. In order to further minimize the false negative results of $\mathrm{HCV}$ infection among cases, cases were selected at the time they were diagnosed before starting treatment, so, immunocompromisation complicating chemotherapy excluded.

After an informed consents were obtained from all subjects before enrollment, study participants were subjected to: detailed history taking and thorough clinical examination, routine laboratory. investigations (CBC, LFT, KFT, INR and urine analysis) and special lab. investigations(detection of anti-HCV antibodies using a third generation enzyme-linked immunosorbent assay (ELISA), determination of HCV RNA PCR in cases and HCV positive controls using COBAS $^{\circledR}$ AmpliPrep/COBAS ${ }^{\circledR}$ Taqman $^{\circledR}$ HCV Test. Detection of cryoglobulinin in cases and $\mathrm{HCV}$ positive controls, [14] and determination of LDH, in all patients [15]. Pelviabdominal ultrasonography was done for all cases and for $\mathrm{HCV}$ positive controls to determine the sonographic state of the liver, spleen, abdominal lymph nodes and to detect the presence of ascites. Pelviabdominal and chest CT and MRI of brain and spinal cord were done for all cases for staging [16]. Histopathologic examination and immunophenotyping were performed at Pathology department, faculty of medicine, Zagazig University. The slides were reviewed blindly without knowledge of virologic state of the patient. Formalin-fixed tissues were stained with haematoxylin and eosin and examined by light microscopy. Type and grade of B cell NHL were defined according to the 2008 World 
Health Organization (WHO) classification of tumours of haematopoietic and lymphoid tissues[17]. Low grade B-NHL included: marginal zone lymphoma (nodal, splenic and extranodal), lymphoplasmocytoid lymphoma and grade 1-2 follicular lymphoma. Intermediate and high grade B-NHL included: diffuse large cell lymphoma, mantle cell lymphoma, Burkitt's lymphoma and grade 3 folliclar lymphoma.

All slides were subjected to immunophenotyping for B- and T-cell markers. Identification of Band $\mathrm{T}$-cell surface markers was carried out using pan-B (CD-20) and pan-T (CD-45) monoclonal antibodies with the DAKO EnVision System (Code No. K4006, DAKO, Carpinteria, CA, USA). Patients with samples that tested positive for the B-cell marker were considered cases, while those positive for the T-cell marker were dropped from the study, regardless of previous classification based on histological examination of haematoxylin and eosin-stained slides.

HCV positive cases and controls with no clinical, laboratory and sonographic evidence of liver cirrhosis underwent a liver biopsy taking. Hepatitis grading and staging were evaluated according to the METAVIR scoring system [18, 19].

Patients were excluded form the study if the had any of the following criteria: patients with B-cell NHL who started treatment for patients collected from the oncology unit, patients who turned out to be T-cell lymphoma by immuno phenotyping, for those collected from tropical medicine department, age less than 15 years old, patients not physically and mentally capable of understanding and completing interview, hepatitis B surface antigen positive patients and HIV patients.

\section{Statistical Analysis}

Data were checked, entered and analyzed using SPSS version 15 for data processing and statistics. Data were expressed as numbers, and percentage for qualitative variables and mean (x) \pm standerd deviation (SD), and range for quantitative variables. Student, $t$, test, and chisquare $\left(X^{2}\right)$ were used when indicated to assess significance, $p<0.05$ was considered significant and highly significant if $\mathrm{p}<0.001$.

\section{RESULTS}

The present study included 50 patients with Bcell NHL and 50 age and sex matched control.

Characteristics for studied groups were represented in table (1). There was statistically significant increase in the percentage of NHL patients who had positive $\mathrm{HCV} \mathrm{Ab}$ and $\mathrm{HCV}$ RNA than control (p, $0.02, \quad p, 0.004$ respectively), also viral loads were higher in $\mathrm{HCV}$ infected patients than HCV infected control without statistically significant difference (p, 0.79) table (2). Liver enzymes and serum bilirubin were significantly increase in $\mathrm{HCV}$ positive cases when compared with $\mathrm{HCV}$ positive control ( $\mathrm{p}<0.001, \mathrm{P}, \quad 0.005$ respectively), table (3). Elevated LDH levels were more common in $\mathrm{HCV}$ positive patients (14 patients out of 18 patients) than HCV negative patients (20 control out of 32 control) without statistically significant difference (p, 0.26 data not shown). Apart from, lymphomatous infiltration in $3 \mathrm{HCV}$ positive patients, and one $\mathrm{HCV}$ positive patient with liver cirrhosis, no significant differences in necro inflammatory activity grading and staging of fibrosis between $\mathrm{HCV}$ positive patients and HCV positive control were recorded (p, 0.24 data not shown).

There was no statistically significant difference in staging, grading and types of NHL between $\mathrm{HCV}$ positive patients and $\mathrm{HCV}$ negative patients table (4). As regard cryoglobulonimia and cryoglobulinemic manifestations, no significant difference between $\mathrm{HCV}$ positive patients and HCV positive control was recorded, table (5). 
Table (1): Demographic data of both studied groups

\begin{tabular}{|c|c|c|c|c|c|c|}
\hline \multirow[t]{2}{*}{ Demographic character } & \multicolumn{2}{|c|}{$\begin{array}{c}\text { Patients } \\
(\mathrm{N}=50)\end{array}$} & \multicolumn{2}{|c|}{ Controls $(\mathrm{N}=50)$} & \multirow[t]{2}{*}{$\mathbf{X} 2$} & \multirow[t]{2}{*}{$P$ value } \\
\hline & Number & $\%$ & Number & $\%$ & & \\
\hline \multicolumn{7}{|l|}{ Age } \\
\hline $15-30$ & 8 & 16.0 & 9 & 18.0 & 0.07 & 0.79 \\
\hline $31-45$ & 15 & 30.0 & 16 & 32.0 & 0.08 & 0.84 \\
\hline $46-60$ & 21 & 42.0 & 20 & 40.0 & 0.08 & 0.86 \\
\hline$\geq 61$ & 6 & 12.0 & 5 & 10.0 & 0.1 & 0.74 \\
\hline \multicolumn{7}{|l|}{ Gender } \\
\hline Male & 31 & 62.0 & 26 & 52.0 & \multirow[t]{2}{*}{1.02} & \multirow[t]{2}{*}{0.31} \\
\hline Female & 19 & 38.0 & 24 & 48.0 & & \\
\hline \multicolumn{7}{|l|}{ Smoking } \\
\hline Non & 33 & 66.0 & 29 & 58.0 & 0.68 & 0.4 \\
\hline Active & 15 & 30.0 & 18 & 36.0 & 0.41 & 0.52 \\
\hline Ex-smoker & 2 & 4.0 & 3 & 6.0 & 0.0 & 1.0 \\
\hline \multicolumn{7}{|l|}{ History of occupational exposure to pesticide } \\
\hline No & 41 & 82.0 & 40 & 80.0 & \multirow[t]{2}{*}{0.06} & \multirow[t]{2}{*}{0.72} \\
\hline Yes & 9 & 18.0 & 10 & 20.0 & & \\
\hline \multicolumn{7}{|l|}{ History of blood transfusion } \\
\hline No & 41 & 82.0 & 46 & 92.0 & \multirow[t]{2}{*}{2.21} & \multirow[t]{2}{*}{0.13} \\
\hline Yes & 9 & 18.0 & 4 & 8.0 & & \\
\hline \multicolumn{7}{|l|}{ History of surgical intervention } \\
\hline Non & 21 & 42.0 & 26 & 52.0 & 1.0 & 0.31 \\
\hline Major operation & 9 & 18.0 & 5 & 10.0 & 1.33 & 0.24 \\
\hline Minor operation (dental manipulation) & 20 & 40.0 & 19 & 38.0 & 0.04 & 0.83 \\
\hline
\end{tabular}

Table (2): Serology and viremia of HCV infection in both studied groups

\begin{tabular}{|c|c|c|c|c|c|c|}
\hline \multirow[t]{2}{*}{ Parameter } & \multicolumn{2}{|c|}{$\begin{array}{c}\text { Cases } \\
(\mathrm{N}=50)\end{array}$} & \multicolumn{2}{|c|}{$\begin{array}{c}\text { Controls } \\
(\mathrm{N}=50)\end{array}$} & \multirow[t]{2}{*}{$X^{2}$} & \multirow[t]{2}{*}{$P$ value } \\
\hline & Number & $\%$ & Number & $\%$ & & \\
\hline \multicolumn{7}{|l|}{ HCV Ab } \\
\hline$-\mathrm{ve}$ & 32 & 64.0 & 42 & 84.0 & \multirow[t]{2}{*}{5.2} & \multirow[t]{2}{*}{0.02} \\
\hline$+\mathrm{ve}$ & 18 & 36.0 & 8 & 16.0 & & \\
\hline \multicolumn{7}{|l|}{ HCV RNA PCR } \\
\hline$+\mathrm{ve}$ & 18 & 36.0 & 6 & 12.0 & 7.89 & 0.004 \\
\hline Viral load (IU X 10 (5) $^{5}$ & & & & & \multicolumn{2}{|l|}{ T test } \\
\hline$\overline{\mathrm{X}} \pm \mathrm{SD}$ & \multicolumn{2}{|c|}{$2.61 \pm 5.3$} & \multirow{2}{*}{\multicolumn{2}{|c|}{$0.076-9.5$}} & \multirow[t]{2}{*}{0.25} & \multirow[t]{2}{*}{0.79} \\
\hline Range & \multicolumn{2}{|c|}{$0.001-20.0$} & & & & \\
\hline
\end{tabular}

$\mathrm{P}<0.05$ significant $\quad \mathrm{P}<0.001$ highly significant 
Table (3): Comparison of lab. investigations of $\mathrm{HCV}$ positive patients and $\mathrm{HCV}$ positive controls

\begin{tabular}{|c|c|c|c|c|}
\hline Lab. test & $\begin{array}{c}\text { HCV positive cases } \\
(N=18)\end{array}$ & $\begin{array}{c}\text { HCV positive controls } \\
(\mathrm{N}=6)\end{array}$ & T test & $P$ value \\
\hline \multicolumn{5}{|c|}{ Liver function tests } \\
\hline \multicolumn{5}{|c|}{ Total bilirubin (mg/dL) } \\
\hline $\mathrm{X} \pm \mathrm{SD}$ & $2.36 \pm 5.2$ & $0.67 \pm 0.25$ & \multirow[t]{2}{*}{7.59} & \multirow[t]{2}{*}{0.005} \\
\hline Range & $0.3-23$ & $0.3-1.2$ & & \\
\hline \multicolumn{5}{|c|}{ Direct bilirubin $(\mathrm{mg} / \mathrm{dL})$} \\
\hline $\mathrm{X} \pm \mathrm{SD}$ & $1.47 \pm 4.1$ & $0.3 \pm 0.19$ & \multirow[t]{2}{*}{5.12} & \multirow[t]{2}{*}{0.02} \\
\hline Range & $0.1-18$ & $0.1-0.8$ & & \\
\hline \multicolumn{5}{|c|}{ S. Albumin (gm/dL) } \\
\hline $\mathrm{X} \pm \mathrm{SD}$ & $3.5 \pm 0.7$ & $3.9 \pm 0.3$ & \multirow[t]{2}{*}{2.95} & \multirow[t]{2}{*}{0.004} \\
\hline Range & $1.7-4.6$ & $3.2-4.5$ & & \\
\hline \multicolumn{5}{|l|}{ ALT } \\
\hline $\mathrm{X} \pm \mathrm{SD}$ & $68.3 \pm 22$ & $36.8 \pm 12.5$ & \multirow[t]{2}{*}{6.45} & \multirow[t]{2}{*}{$<0.001$} \\
\hline Range & $33-120$ & $18-77$ & & \\
\hline \multicolumn{5}{|l|}{ AST } \\
\hline $\mathrm{X} \pm \mathrm{SD}$ & $70.8 \pm 22$ & $35.8 \pm 8.6$ & \multirow[t]{2}{*}{7.99} & \multirow[t]{2}{*}{$<0.001$} \\
\hline Range & $38-114$ & $21-55$ & & \\
\hline \multicolumn{5}{|l|}{$\mathrm{CBC}$} \\
\hline \multicolumn{5}{|l|}{$\mathrm{Hb}(\mathrm{gm} / \mathrm{dL})$} \\
\hline $\mathrm{X} \pm \mathrm{SD}$ & $10.9 \pm 2.1$ & $12.2 \pm 2$ & \multirow[t]{2}{*}{2.09} & \multirow[t]{2}{*}{0.04} \\
\hline Range & $6.1-12.8$ & $8.6-14.1$ & & \\
\hline \multicolumn{5}{|c|}{ PLT count $\left(\times 10^{3} / \mathrm{mm}^{3}\right)$} \\
\hline $\mathrm{X} \pm \mathrm{SD}$ & $182 \pm 75$ & $186 \pm 49$ & \multirow[t]{2}{*}{0.22} & \multirow[t]{2}{*}{0.82} \\
\hline Range & $72-290$ & $97-310$ & & \\
\hline \multicolumn{5}{|c|}{ WBC count $\left(\mathrm{x} \mathrm{10}^{3} / \mathrm{mm}^{3}\right)$} \\
\hline $\mathrm{X} \pm \mathrm{SD}$ & $6.8 \pm 2.6$ & $7.1 \pm 2$ & \multirow[t]{2}{*}{0.49} & \multirow[t]{2}{*}{0.62} \\
\hline Range & $3.5-12.5$ & $3.9-10.2$ & & \\
\hline \multicolumn{5}{|l|}{ INR } \\
\hline $\mathrm{X} \pm \mathrm{SD}$ & $1.2 \pm 0.2$ & $1.03 \pm 0.05$ & \multirow[t]{2}{*}{1.9} & \multirow[t]{2}{*}{0.31} \\
\hline Range & $1-1.8$ & $1-1.2$ & & \\
\hline
\end{tabular}


Table (4): Comparison of histopathologic types, grading and staging of B cell NHL in HCV positive patients and HCV negative patients

\begin{tabular}{|c|c|c|c|c|c|c|}
\hline \multirow[t]{2}{*}{ Type of NHL } & \multicolumn{2}{|c|}{$\begin{array}{l}\text { HCV positive } \\
\text { patients }(N=18)\end{array}$} & \multicolumn{2}{|c|}{$\begin{array}{l}\text { HCV negative } \\
\text { patients }(\mathrm{N}=32)\end{array}$} & \multirow[t]{2}{*}{$\mathbf{X}^{2}$} & \multirow[t]{2}{*}{ P value } \\
\hline & Number & $\%$ & Number & $\%$ & & \\
\hline Biffuse large B cell lymphoma & 6 & 33.3 & 15 & 46.9 & 0.87 & 0.35 \\
\hline Follicular lymphoma & 3 & 16.7 & 7 & 21.9 & 0.01 & 0.94 \\
\hline Small cell lymphoma/ chronic lymphatic leukemia & 2 & 11.1 & 2 & 6.3 & 0.01 & 0.94 \\
\hline Marginal zone lymphoma & 2 & 11.1 & 2 & 6.3 & 0.01 & 0.94 \\
\hline MALT lymphoma & 1 & 5.6 & 3 & 16.7 & 0.01 & 0.94 \\
\hline Mantle cell lymphoma & 1 & 5.6 & 2 & 6.3 & 0.27 & 0.68 \\
\hline Lymphoplasmacytic lymphoma & 2 & 11.1 & 0 & 0.0 & 1.38 & 0.24 \\
\hline Burkitt lymphoma & 1 & 5.6 & 1 & 3.1 & 0.11 & 0.74 \\
\hline \multicolumn{7}{|l|}{ Grade of NHL } \\
\hline Low & 6 & 33.3 & 13 & 40.6 & 0.26 & 0.61 \\
\hline Intermediate & 4 & 22.2 & 8 & 25.0 & \begin{tabular}{|l|}
0.02 \\
\end{tabular} & 0.82 \\
\hline High & 8 & 44.5 & 11 & 34.4 & 0.5 & 0.48 \\
\hline \multicolumn{7}{|l|}{ Staging of NHL } \\
\hline I & 4 & 22.2 & 5 & 15.6 & 0.04 & 0.56 \\
\hline II & 5 & 27.8 & 12 & 37.5 & 0.49 & 0.48 \\
\hline III & 3 & 16.7 & 10 & 31.3 & 0.63 & 0.42 \\
\hline IV & 6 & 33.3 & 5 & 13.6 & 1.2 & 0.27 \\
\hline
\end{tabular}

Table (5): Comparison of cryoglobulinemia among $\mathrm{HCV}$ positive patients and $\mathrm{HCV}$ positive controls

\begin{tabular}{|l|c|c|c|c|c|c|}
\hline \multirow{2}{*}{ Parameter } & \multicolumn{2}{|c|}{$\begin{array}{c}\text { HCV positive } \\
\text { patients (N=18) }\end{array}$} & \multicolumn{2}{c|}{$\begin{array}{c}\text { HCV positive } \\
\text { controls (N=6) }\end{array}$} & \multirow{2}{*}{$\mathbf{X}^{\mathbf{2}}$} & \multirow{2}{*}{ P value } \\
\cline { 2 - 6 } & Number & $\%$ & Number & $\%$ & & \\
\hline Cryoglobulinemia & 10 & 55.6 & 4 & 66.7 & 0.0 & 1.0 \\
\hline No & 8 & 44.4 & 2 & 33.3 & & \\
\hline Yes & 2 & 11.1 & 0 & 0.0 & 0.73 & 0.39 \\
\hline $\begin{array}{l}\text { Cryoglobulinemic manifestations in } \\
\text { the cryo +ve patients }\end{array}$ & & & & & \\
\hline
\end{tabular}

\section{DISCUSSION}

$\mathrm{HCV}$ association with B cell NHL is still a matter of debate, no association between $\mathrm{HCV}$ infection and B cell NHL was found [8, 9]. Most of the studies that failed to find an association of $\mathrm{HCV}$ with B cell NHL were conducted in areas where the prevalence of $\mathrm{HCV}$ is extremely low; leaving open the possibility that such an association actually exists but could not be detected because neither cases nor controls had adequate opportunity for exposure to the virus [10].

Working in a population with the highest prevalence of HCV allowed us to conduct a casecontrol study with adequate statistical power to assess the question of whether there is an association of chronic HCV infection with B cell NHL [11].

The present study shows that the incidence of $\mathrm{HCV}$ active infection among the control group is $12 \%$ (6 out of 50 control), $16 \%$ of controls were $\mathrm{HCV}$ antibody positive, $2 \mathrm{HCV}$ Ab positive control were HCV RNA PCR negative, that mean they cleared viremia. About $15 \%$ of the Egyptian had HCV positive anti bodies while $10 \%$ had active infection with positive $\mathrm{HCV}$ RNA PCR. [20, 21]

The incidence of $\mathrm{HCV}$ infection among cases was $36 \%$ (18 out of 50 cases). All cases were positive for HCV antibodies and for HCV RNA PCR; that mean none of the infected cases could clear viremia. This finding can be explained by the fact that B cell NHL is a sequel of disordered 
immune system which can't successfully clear viremia [11].

The occurrence of HCV active infection among cases was statistically significantly higher than in controls (p 0.004). These results suggest a positive association between $\mathrm{HCV}$ infection and B cell NHL $[11,22]$.

Studies which failed to find an association were carried out in communities with low prevalence of HCV infection. Their results may be explained by the smaller sample size of their studies than that required to obtain an adequate statistical power or by that the spread of $\mathrm{HCV}$ in those communities is relatively recent and not having enough time to be complicated by NHL [23].

$\mathrm{HCV}$ viral loads were higher in $\mathrm{HCV}$ associated B cell NHL patients compared to HCV infected controls without statistically significant difference ( $p, 0.79)$. This finding is in agreement with that obtained by Karavattathayyil et al., [24] who demonstrated actively replicating virus in $\mathrm{HCV}$-associated lymphomas.

There was a statistically highly significant increase in liver enzymes levels between HCV positive patients and $\mathrm{HCV}$ positive controls ( $\mathrm{p}$ value $<0.001)$. This finding may be due to:

Lymphomatous infiltration of the liver in HCV positive patients and Chemotherapy induced hepatotoxicity in HCV associated patients [12]. There was no statistically significant difference in liver enzymes levels between HCV positive patients and $\mathrm{HCV}$ negative patients. Liver enzymes levels were elevated in both groups but higher values occurred in HCV positive patients $[12,13]$.

There was no statistically significant difference between different histological types of $\mathrm{HCV}$ associated lymphomas. In the present study, the commonest types of HCV associated B cell NHL were diffuse large $\mathrm{B}$ cell lymphoma which is an aggressive lymphoma followed by follicular lymphoma which may be indolent or aggressive. This is in concordance with Goldman et al. [25], who found that $\mathrm{HCV}$ is associated with diffuse large B cell, marginal zone, and follicular lymphomas. While others, found that lymphoplasmacytoid lymphoma/immunocytoma and Waldenströmmacroglobulinemia, were the only NHL associated to HCV, because they studied patients with $\mathrm{HCV}$ associated essential mixed cryoglobulinemia (EMC) in whom that types of NHL are a common complication [22,
26, 27]. The results of the present study showed that $\mathrm{HCV}$ is associated with de novo NHL not complicating essential mixed cryoglobulinemia (EMC).

The percentage of HCV positive patients who had cryoglobulinemia (44.4\%) was higher than those with $\mathrm{HCV}$ positive control $(33.3 \%)$ without significant difference. $2 \mathrm{HCV}$ positive NHL patients had cryoglobulinemic manifestations in the form of purpura, arthralgia and microscopic hematuria for many years before the diagnosis of lymphoplasmacytic lymphoma. However, others found that $\mathrm{HCV}$ associated lymphoma, were overt B cell lymphomas that complicate essential mixed cryoglobulinemia (EMC) with up to $30 \%$ of cases associated with hepatitis $C[22,26,27]$. Our results showed that $\mathrm{HCV}$ is linked to de novo B cell lymphoproliferative disorders not complicating mixed cryoglobulinemia (EMC). The difference form our result is attributed to difference in selection criteria as, they selected patients with EMC as an inclusion criteria.

Funding: Non .

Conflicts of interest: The authors declare that there is no conflict of interest.

Ethical approval: approved.

\section{REFERENCES}

1. Lavanchy D, McMahon B. Worldwide prevalence and prevention of hepatitis C. Biomedical research reporte, ELSEVIER 2000; 2 : 185-201.

2. Frank C, Mohamed M, Strickland G, Lavanchy $\mathrm{D}$, Arthur R, Magder LS et al. The role of parenteral antischistosomal therapy in the spread of hepatitis C virus in Egypt. Lancet 2000; 355:887-91.

3. Habib M, Mohamed M, Abdel-Aziz, Magder L.S , Abdel-Hamid M , Gamil F et al. Hepatitis C virus infection in a community in the Nile delta: risk factors for seropositivity. Hepatology 2001;33:248-53.

4. Alter MJ . Epidemiology of Hepatitis C., Hepatolgy 1997; 26 (3): 625-665.

5. Agnello V. Mixed cryoglobulinemia and other extrahepatic manifestations of hepatitis $C$ virus infection. ELSEVIER 2000; 2: 295-313.

6. Quinn E, Chan C ,Hadlock K. ,Foung S, Flint $\mathrm{M}$, Levy S. The B-cell receptor of a hepatitis C virus (HCV)-associated non-Hodgkin lymphoma binds the viral E2 envelope protein, implicating HCV in lymphomagenesis. Blood 2001; 98: 3745-49.

7. Ivanovski M, Silvestri F, Pozzato G, Anand S, Mazzaro C, Burrone RO et al. Somatic hypermutation, clonal diversity, and preferential 
expression of the $\mathrm{VH}$ 51p1/VL Kv325 immunoglobulin gene combination in hepatitis $\mathrm{C}$ virus-associated immunocytomas. Blood 1998;91:2433-42.

8. Varma S, Menon, M, Garg A, Malhotra P, Sharma A, Chawla Y et al. Hepatitis C virus infection among patients with non-Hodgkin's lymphoma in northern India. Hepatol Int. 2011; 5(2): 688-692.

9. Prasitthipayong A, Homchaem P, Pornsopone, $\mathrm{P}$ , Temiyasathit S, Kunka C, Klinvimol T et al . Effect of hepatitis $\mathrm{C}$ viruson the risk of nonHodgkin's lymphoma in Thailand. Thai Cancer J. 2008; 28: 114-121.

10. Turner N, Dusheiko G, Jones A. Hepatitis C and B-cell lymphoma. Annals of Oncology 2003, 14: 1341-1345.

11. Cowgill K., Loffredo C, Eissa S, Mukhtar N, Abdel-Hamid M , Fahmy, et al. case-control study of non-Hodgkin's lymphoma and hepatitis $\mathrm{C}$ virus infection in Egypt. International Journal of Epidemiology 2004; 33: 1034-39.

12. Alam El-Din H, Loutfy S. Hepatitis C Virus Infection in Non-Hodgkin's Lymphoma Patients: Virological Evaluation. Kuwait Medical Journal 2006; 38 (2): 122-127.

13. Pellicelli A, Marignani M, Zoli V, Romano M , Morrone A, Nosotti L et al. Hepatitis C virusrelated B cell subtypes in non Hodgkin's lymphoma. World J Hepatol 2011; 3(11): 278284.

14. Ferri C, Zignego A, Pileri S. Cryoglobulins. Journal of Clinical Pathology2002; 55(1): 4-13.

15. Burtis C, Ashwood E. Tietz Textbook of Clinical Chemistry. Philadelphia, WB Saunders Company $2001: 811-13$.

16. James O. Staging non Hodjkin lymphoma. Cancer Journal for Clinician 2005; 55, (6): 368376.

17. Swerdlow S, Campo E, Harris N, Jaffe E, Pileri, S, Stein H et al. 2008 World Health Organization (WHO): classification of tumours. Tumours of haematopoietic and lymphoid tissue. Lyon: IARC Press 2008: 267-268.
18. Bedossa P, Poynard T, the French METAVIR Cooperative Study Group . An algorithm for grading activity in chronic hepatitis $\mathrm{C}$. Hepatology 1996; 24: 289-93.

19. Poyanrd T, Bedossa P, Opolon P. Natural history of liver fibrosis progression in patients with chronic hepatitis C. The OBSVIRC, METAVIR CLINIVIR and DOSVIRC groups. Lancet 1997; 349: 825-32.

20. Mohamed M. Epidemiology of HCV in Egypt 2004. The Afro-Arab Liver Journal2004; 3(2): 41-52.

21. El Zanaty F , Way A . Knowledge and prevalence of hepatitis C.EDHs2009: 251-258.

22. Ferri C, Caracciolo F, Zignego A. Hepatitis C virus infection in patients with non-Hodgkin's lymphoma. Br J Haematol 1994; 88(2): 392-394.

23. Marcucci F, Mele A. Hepatitis viruses and nonHodgkin lymphoma: epidemiology, mechanisms of tumorigenesis, and therapeutic opportunities. Blood 2011; 117(6): 1792-1798.

24. Karavattathayyil S, Kalkeri G, Liu H, Gaglio P , Garry RF , Krause JR et al. Detection of hepatitis $\mathrm{C}$ virus RNA sequences in B-cell nonHodgkin lymphoma. Am J ClinPathol 2000; 113: 391-398.

25. Goldman L, Ezzat S, Mokhtar N, Abdel-Hamid A , Fowler N, Gouda I et al. Viral and non-viral risk factors for non-Hodgkin's lymphoma in Egypt: heterogeneity by histological and immunological subtypes. Cancer Cases Control 2009; 20(6): 981-7.

26. Mussini, C, Ghini M, Mascia M, Giovanardi P, Zanni G, Lattuda $\mathrm{I}$ et al. Monoclonal gammopathies and hepatitis $\mathrm{C}$ virus infection. Blood 1995; 85(4): 1144-1149.

27. Silvestri F, Barillari G, Fanin R, Salmaso F, Pipan C, Falasca E et al. Impact of hepatitis C virus infection on clinical features, quality of life and survival of patients with lymphoplasmacytoid lymphoma/immunocytoma. Ann Oncol 1998; 9: 499-504. 